Review

\title{
Genetic Polymorphisms Associated with Spontaneous Intracerebral Hemorrhage
}

\author{
Yi-Chun Chen ${ }^{\circledR}$, Kuo-Hsuan Chang and Chiung-Mei Chen * \\ Department of Neurology, Chang Gung Memorial Hospital Linkou Medical Center and College of Medicine, \\ Chang-Gung University, No. 5, Fuxing St., Guishan Township, Taoyuan County 333, Taiwan; \\ asd108@adm.cgmh.org.tw (Y.-C.C.); gophy5128@cloud.cgmh.org.tw (K.-H.C.) \\ * Correspondence: cmchen@adm.cgmh.org.tw; Tel.: +886-3-3281200 (ext. 8729)
}

Received: 27 October 2018; Accepted: 3 December 2018; Published: 4 December 2018

check for updates

\begin{abstract}
Differences in the incidence of spontaneous intracerebral hemorrhage (ICH) between ethnicities exist, with an estimated $42 \%$ of the variance explained by ethnicity itself. Caucasians have a higher proportion of lobar ICH (LICH, $15.4 \%$ of all ICH) than do Asians (3.4\%). Alterations in the causal factor exposure between countries justify part of the ethnic variance in ICH incidence. One third of ICH risk can be explained by genetic variation; therefore, genetic differences between populations can partly explain the difference in ICH incidence. In this paper, we review the current knowledge of genetic variants associated with ICH in multiple ethnicities. Candidate gene variants reportedly associated with ICH were involved in the potential pathways of hypertension, vessel wall integrity, lipid metabolism, endothelial dysfunction, inflammation, platelet function, and coagulopathy. Furthermore, variations in APOE (in multiple ethnicities), PMF1/SLC25A44 (in European), ACE (in Asian), MTHFR (in multiple ethnicities), TRHDE (in European), and COL4A2 (in European) were the most convincingly associated with $\mathrm{ICH}$. The majority of the associated genes provide small contributions to ICH risk, with few of them being replicated in multiple ethnicities.
\end{abstract}

Keywords: intracerebral hemorrhage; genetics; association studies; ethnicities

\section{Introduction}

Spontaneous intracerebral hemorrhage (ICH) is a devastating stroke subtype, which accounts for $8-10 \%$ and $22-35 \%$ of all stroke patients in Western countries [1-3] and in the Asian population [4-6], respectively. An estimated $42 \%$ of the variance in ICH incidence was explained by ethnicity, given that ICH incidence in the Asian population (51.8 per 100,000 person-years) doubled that seen in Caucasians (24.2) [7]. The majority of ICH $(65-80 \%)$ occurs in deep brain regions (DICH), including the basal ganglia, thalamus, brainstem, and cerebellum. Further, lobar ICH (LICH) and DICH differ based on both their risk factors and pathogenesis [8,9]. Risk factors for ICH vary by location of hemorrhage. Specifically, while LICH was partially attributable to cerebral amyloid angiopathy (CAA), particularly in the elderly, considering that the amyloid deposits are primarily located in cortical vessels, hypertension is the main cause of $\mathrm{DICH}$ instead (>80\%) [10]. Other risk factors of ICH include excessive use of alcohol, which impairs coagulation and directly affects cerebral vessel integrity, low serum cholesterol levels, and other factors which cause coagulopathy or vasculopathy [8]. Interestingly, Caucasians reported a higher proportion of LICH (15.4\% of all ICH) than did Asians (3.4\%) [10]. Additionally, American blacks have higher ICH rates in young and middle-aged people than whites, particularly for DICH [11]. Further, men have younger age of ICH than women among Asians [12]. Differences in the exposure to causal factors, the control of hypertension and cholesterol, and the anticoagulant and antiplatelet treatment for stroke between countries and genders explain an important portion of the variance observed in ICH incidence between ethnicities [10] and genders [13-16]. However, a significant part of this variation remains unexplained. 
Approximately $30 \%$ of the risk factors of ICH were estimated to be undefined, or a result of a family history of such a condition [17]. ICH in a first-degree relative was reported to increase an individual's odds for developing ICH six-fold. [18]. Additionally, monogenetic disorders associated with ICH account for less than $1 \%$ of all ICH and typically occur in childhood or young adults, such as genes related to cerebral cavernous malformations (CCMs) and cerebral autosomal dominant arteriopathy with subcortical infarcts and leukoencephalopathy (CADASIL) $[19,20]$. Given that one-third of the risk factors related to ICH can be explained by both common and rare genetic variations, the genetic differences between populations can partly elucidate the variation in ICH incidence observed [21]. Prior reports of ICH genetics are mainly approached by selecting candidate genetic variations, which are involved in the possible underlying pathogenic pathways and associated with potential environmental risk factors. However, many of the candidate genetic studies were limited by the small sample size, ethnicity disparities, and selection bias for phenotypes, leading to inconsistent results. Because of the advance in genotyping technologies, which are capable of assessing more than 500,000 to 1 million single nucleotide polymorphisms (SNPs) in a single sample, genome wide association studies (GWA) are now able to extensively examine the genetic factors of common diseases. The benefit of GWA is that it permits thousands of genome wide comparisons without a priori knowledge of target genetic function. Identification of genetic risk factors may shed light on possible underlying pathogenesis, potential therapeutic targets, and disease prevention strategies. Therefore, this review focuses on the available data reported in English on the PubMed, including candidate genetic studies (with number of ICH cases > 100), meta-analysis, and GWA to discuss the common genetic variations associated with ICH between ethnicities.

\section{Common Genetic Predisposition of ICH}

Candidate gene variants reported to be associated with ICH were potentially involved in the following pathways: hypertension, vessel wall integrity, lipid metabolism, endothelial dysfunction, inflammation markers, platelet function, and coagulopathy [22,23]. We will discuss the reported genetic variations according to the underlying mechanisms in the following sections. Genome Reference Consortium Human Build 38 (GRCh38) is used for denoting the genomic positions of the variations.

\subsection{Genetic Variants Related to the Renin-Angiotensin System (Table 1)}

Hypertension represents the most critical risk factor of $\mathrm{ICH}$, accounting for about $54 \%$ of $\mathrm{ICH}$ cases [18]. In fact, the renin-angiotensin system controls BP by regulating the volume of fluids in the body. Further, the angiotensin I converting enzyme (ACE) is an integral membrane protein which converts angiotensin I, a hormone, to angiotensin II, an active vasoconstrictor, leading to vasoconstriction and inhibition of bradykinin.

\section{Angiotensin I Converting Enzyme (ACE)}

Cytogenetic location: 17q23.3, 21 kb, main risk variant: rs1799752 (chr17:63488530-63488543, intron variant: Alu sequence). The rs1799752 variant implies either an insertion (I allele) or a deletion (D allele, lacks the repetitive element) of an Alu repetitive sequence in intron 16. When compared to the II genotype, the DD genotype correlates with increased ACE activity [24]. Additionally, increased vasoconstriction results in an increased risk of developing ICH. The largest meta-analysis [25] examined 33 studies (3355 ICH cases and 4722 controls), and reported the D allele to be a risk factor of ICH in the Asian population only (28 of 33 studies), as the same was not valid for the Caucasians $[25,26]$. In fact, Asian ICH patients were more likely to have hypertension than Caucasian patients [10]. Although we indicated the association between the D allele and DICH to be mediated by hypertension [27], the mechanisms that link the rs1799752 polymorphism to ICH, especially to $\mathrm{LICH}$, are yet to be defined. Additionally, the D allele was described as the major allele in Caucasians [28], regardless of the absence of association between rs1799752 and the risk of developing ICH. Other mechanisms including inflammation [29], vascular remodeling [30], and the amyloid- $\beta(\mathrm{A} \beta)$ metabolism [31] may cause the disparities in ACE susceptibility found between ethnicities. 
Table 1. Variants associated with spontaneous intracerebral hemorrhage (ICH): hypertension and vascular integrity.

\begin{tabular}{|c|c|c|c|c|c|c|c|c|}
\hline $\begin{array}{l}\text { Gene Name and } \\
\text { Abbreviation }\end{array}$ & Protein Function & Variant Locus & Population & $\begin{array}{c}\text { No of } \\
\text { Cases/Controls }\end{array}$ & $\begin{array}{c}\text { MAF of } \\
\text { Cases/Controls }\end{array}$ & OR $(95 \% \mathrm{CI})$ & Ref & Notes \\
\hline \multirow{2}{*}{$\begin{array}{c}\text { Angiotensin-converting } \\
\text { enzyme ( } A C E)\end{array}$} & \multirow{2}{*}{$\begin{array}{c}\text { Converts } \\
\text { angiotensin I to } \\
\text { angiotensin II }\end{array}$} & \multirow{2}{*}{$\begin{array}{l}\text { rs1799752: intron } \\
\text { variant: Alu } \\
\text { sequence }\end{array}$} & Asian & $2941 / 3715$ & D 0.44/0.37 & $\begin{array}{l}\text { Rec: } 1.98 \text { (1.53-2.57); } \\
\text { Dom: } 1.31 \text { (1.18-1.45) }\end{array}$ & [25] & $\begin{array}{r}\text { Meta-analysis in } \\
\text { LICH + DICH; }\end{array}$ \\
\hline & & & Caucasian & $414 / 1007$ & $\begin{array}{l}\text { I } 0.36 / 0.48 \text { [28] } \\
\text { I } 0.57 / 0.47 \text { [32] }\end{array}$ & No significance & {$[25,26]$} & $\begin{array}{l}\text { Meta-analysis in } \\
\text { LICH + DICH; }\end{array}$ \\
\hline $\begin{array}{c}\text { Alpha-2 type IV } \\
\text { collagen (COL4A2) }\end{array}$ & $\begin{array}{c}\text { Abundant } \\
\text { component of the } \\
\text { cerebral vasculature } \\
\text { basement } \\
\text { membranes. }\end{array}$ & $\begin{array}{l}\text { intron variants: } \\
\text { rs9521732 C>A; } \\
\text { rs9521733 T>C; } \\
\text { rs9515199 C>T }\end{array}$ & European & $1545 / 1485$ & $\begin{array}{l}\text { A } 0.41 / 0.46 ; \\
\text { C 0.40/0.43; } \\
\text { T0.41/0.47 }\end{array}$ & $\begin{array}{c}\text { Add: } 1.28(1.13-1.44) ; \\
1.29(1.14-1.46) ; \\
1.28(1.14-1.44)\end{array}$ & [33] & $\begin{array}{c}\text { Meta-analysis, } \\
\text { Significant in } \\
\text { DICH; }\end{array}$ \\
\hline \multirow{2}{*}{$\begin{array}{c}\text { Tissue metalloproteinase } \\
\text { inhibitor } 1 \text { (TIMP-1) }\end{array}$} & \multirow{4}{*}{$\begin{array}{c}\text { Inhibits matrix } \\
\text { metalloproteinases } \\
\text { and promotes cell } \\
\text { proliferation. }\end{array}$} & $\begin{array}{l}\text { rs2070584: intron } \\
\text { variant } A>C\end{array}$ & Chinese & 275/145 (male) & $0.54 / 0.43$ & $1.54(1.03-2.3)$ (male) & {$[34]$} & $\mathrm{LICH}+\mathrm{DICH}$ \\
\hline & & $\begin{array}{l}\text { rs4898: intron } \\
\text { variant } \mathrm{T}>\mathrm{C}\end{array}$ & Taiwanese & 228/212 (male) & $0.39 / 0.45$ & $0.35(0.15-0.81)$ (male) & [13] & $\mathrm{DICH}$ \\
\hline \multirow{2}{*}{ TIMP-2 } & & $\begin{array}{l}\text { rs7503726: 5' UTR } \\
\text { variant G>A }\end{array}$ & German & $45 / 253$ & $\begin{array}{c}0.4 / 0.37 \\
\text { (total stroke) }\end{array}$ & Rec: $2.02(1.1-3.7)$ & [35] & $\mathrm{LICH}+\mathrm{DICH}$ \\
\hline & & $\begin{array}{l}\text { rs7503607: 5' UTR } \\
\text { variant C>A }\end{array}$ & Taiwanese & $396 / 376$ & $0.18 / 0.13$ & $\begin{array}{l}\text { Add: } 2.5 \text { (1.37-4.38) } \\
\quad \text { (elder group) }\end{array}$ & [14] & $\mathrm{DICH}$ \\
\hline
\end{tabular}

MAF: Minor allele frequency (MAF), OR: odds ratio, Ref: references, Rec: recessive model, Dom: dominant model, Add: additive model, 5' UTR: 5' untranslated region. 


\subsection{Genetic Variants Related to Vessel Wall Integrity (Table 1)}

With persistent hypertension, smooth muscle cell proliferation in the cerebral arterioles occurs with the formation of reactive hyperplasia, replaced by collagen tissues, on the vascular walls [30]. Specifically, when the deposition of collagen becomes insufficient, the arteriolar wall will dilate and result in a Charcot-Bouchard aneurysm, which weakens vascular integrity [36]. Bleeding of the aneurysm is mainly determined by the extent of the vascular pathological changes, individuals' systemic blood pressure and other factors regulating hemostasis [8].

\subsubsection{Collagen, Type IV, Alpha-2 (COL4A2)}

Cytogenetic location: 13q34, $206 \mathrm{~kb}$, main risk variants: intron variants: rs9521732 (chr13:110381474, C>A), rs9521733 (chr13:110382195, T>C), and rs9515199 (chr13:110381357, C>T). Both COL4A1 and COL4A2 are highly expressed in the vascular basement membranes and were associated with an increased risk of small vessel diseases, especially ICH [33]. Specifically, three nonsynonymous coding mutations (COL4A2/ p.E1123G, p.Q1150K, and p.A1690T) were reported to contribute to the sporadic Caucasian cases of ICH in an autosomal dominant phenotype [37]. These mutations impaired both COL4A1 and COL4A2 secretion, and caused their intracellular retention within the endoplasmic reticulum (ER), leading to ER stress and cytotoxicity. Furthermore, other structurally-related variants (COL4A1/p.P352L and p.R538G) were described to trigger sporadic late-onset ICH [38].

A meta-analysis on the common genetic variation within both COL4A1 and COL4A2 among individuals of European ancestry identified three intronic SNPs (rs9521732, rs9521733, and rs9515199) in COL4A2 to be significantly associated with DICH [33]. In contrast, there was no reported replication study in ethnic groups of non-European ancestry.

\subsubsection{Tissue Inhibitors of Metalloproteinase-1 (TIMP-1) and TIMP-2}

TIMP-1 Cytogenetic location: Xp11.3, 4.5 kb, main risk variant: rs2070584 (chrX:47587120, intron variant, $\mathrm{A}>\mathrm{C}$ ) and main protective variant: $\mathrm{rs} 4898$ (chrX:47585586, intron variant, $\mathrm{T}>\mathrm{C}$ ). TIMP-2 Cytogenetic location: 13q34, $206 \mathrm{~kb}$, main risk variants (5' untranslated region, $5^{\prime} \mathrm{UTR}$ ): rs7503726 (chr17:78925349, G>A) and rs7503607 (chr17:78925357, C>A).

Matrix metalloproteinases (MMPs) are a family of zinc/calcium-dependent endopeptidases which digest both the extracellular matrix (ECM) and the basal lamina [39], causing a blood-brain barrier breakdown and activating an inflammatory reaction [40]. Among MMPs, gelatin-binding MMPs were particularly unique in BBB damage because of their ability to digest type IV and type V collagen, which are the essential constituents of vascular basement membrane in the vascular endothelium. Degradation of the collagen tissues may break down the vessel integrity, which is responsible for the eventual rupture of the vessel walls [41-43]. MMP activity is suppressed by tissue inhibitors of metalloproteinases (TIMPs). Each TIMP was able to interact with any of the MMPs; however, certain combinations between MMPs and TIMPs have been reported, in which TIMP-1 is the main endogenous inhibitor to MMP-9 while TIMP-2 is to MMP-2 [43,44]. A mouse model showed neuroprotection by inhibition of MMPs in acute ICH, suggesting a therapeutic strategy for the treatment of acute brain injury after ICH [45]. Additionally, TIMP-1 and TIMP-2 were shown to have a protective role for the progression of cerebral aneurysms, which suggests that TIMPs may help prevent the degradation of ECM and rupture of cerebral aneurysms [46]. Considering that TIMP-1 locates to the $\mathrm{X}$ chromosome, its effect is more prominent in males than females. Further, while an intronic polymorphism of TIMP-1 rs2070584 C allele is associated with ICH in Chinese male patients [34], C allele of rs4898 provides a protective effect on DICH risk in the elderly male group [13]. Additionally, although the TIMP-2 AA rs7503726 genotype increased the risk of developing ICH in a genetic recessive model conducted on the German population [35], it was considered a protective factor against DICH in elderly Taiwanese females [14]. The disparity between the two reports may be due to different minor allele frequency (MAF) (39.14\% in the former and $49.7 \%$ in the latter), heterogeneity of phenotypes, and stratification of 
subgroups in the latter report. Overall, the imbalance between MMPs and TIMPs may be responsible for ECM degradation, resulting in the progression and rupture of damaged vessels.

\subsection{Genetic Variants Related to Lipid Metabolism (Table 2)}

\subsubsection{Apolipoprotein E (APOE)}

Cytogenetic location: $19 q 13.32,3 \mathrm{~kb}$, main risk variant: $\varepsilon 2$ and $\varepsilon 4 . A P O E \varepsilon 2 / \varepsilon 3 / \varepsilon 4$ alleles are haplotypes constructed by two missense variants, rs7412 (chr19:44908822, C>T) and rs429358 (chr19:44908684, T>C). APOE $\varepsilon 3 \varepsilon 3$ is the most common genotypes. Both $\varepsilon 2$ and $\varepsilon 4$ are missense variants. The APOE gene produces three apolipoprotein (APOE) isoforms which interact differently with specific lipoprotein receptor and thus influence cholesterol level. In general, the $\varepsilon 2$ allele is associated with lower serum total cholesterol levels, and $\varepsilon 4$ raises them [47]. APOE transports lipoproteins, fat-soluble vitamins, and cholesterol, and is involved in cell membrane maintenance and repair [48]. The $\varepsilon 2$ or $\varepsilon 4$ alleles are associated with an increase in both $\beta$-amyloid protein deposition and fibrinoid necrosis in the vessel wall, which augments the vasculopathy effects of amyloid deposition in cerebral vessels [49]. A population study suggested that carrying either the $\varepsilon 2$ or the $\varepsilon 4$ raised the risk of developing both DICH and LICH [50]. Specifically, Asian carriers had a doubled risk of developing DICH, whereas Europeans reported a tripled risk of LICH [50]. Additionally, a genome-wide association study conducted on the European population (2189 ICH cases and 4041 controls) identified both the $\varepsilon 2$ and the $\varepsilon 4$ to be risk factors for developing LICH, whereas $\varepsilon 4$ was associated with DICH [51]. Furthermore, another meta-analysis including 11 case-control studies (1238 ICH cases and 3575 controls) showed that ICH cases had a significantly higher frequency of the APOE $\varepsilon 4$ allele [52]. Specifically, ICH cases had a significantly higher frequency of the APOE $\varepsilon 4$ allele in both Asians and Caucasians. However, they did not find a significant relationship between the $A P O E \varepsilon 2$ allele and the risk of ICH [52]. A meta-analysis of 58 studies (6855 participants), investigating both the APOE genotype and sporadic CAA, showed convincing evidence of a dose-dependent association between the $\varepsilon 4$ and sporadic CAA [53], consistent with their associations with $\mathrm{LICH}$.

\subsubsection{ER Lipid Raft Associated 1 (ERLIN1)}

Cytogenetic location: 10q24.31, $35 \mathrm{~kb}$, main protective variant (upstream variant): $\mathrm{rs} 1324694$ (chr10:100186688, C>T). ERLIN1 is a component of lipid rafts, and is specifically localized to the endoplasmic reticulum and the nuclear envelope. ERLIN1 is involved in cellular cholesterol homeostasis and in defining the lipid-raft-like domains of the endoplasmic reticulum [54]. The association between rs1324694 and ICH was found in a Japanese cohort [54], in which the rs1324694 minor allele (T) in the $5^{\prime}$ region of ERLIN1 was significantly related to $\mathrm{ICH}$, and was reported to have a protective role. However, to date, a replication study has not yet been reported.

\subsubsection{Low-Density Lipoprotein Receptor (LDLR)}

Cytogenetic location: 19p13.2, $44 \mathrm{~kb}$, main protective variant (synonymous variant): $\mathrm{rs} 688$ (chr19:11116926, C>T). According to the Ensemble annotation, the most severe consequence of rs688 is a synonymous variant. The LDLR is a cell surface receptor that plays an important role in cholesterol homeostasis. The minor rs688 variant is an intron variant that directly affects exon 12 alternative splicing, and is related to increases in plasma cholesterol levels [55]. Its association with ICH was found in a single Taiwanese cohort, which suggested the homozygous minor allele $\mathrm{T}$ to be correlated with a $73 \%$ decreased risk of developing ICH [56].

\subsubsection{Apolipoprotein (a) (LPA)}

Cytogenetic location: 6q25-q26, $134 \mathrm{~kb}$, main risk pentanucleotide variant: TTTTA repeat in $5^{\prime}$ UTR - 1373 upstream of the transcription start site. LPA encodes apolipoprotein (a) which forms the lipoprotein Lp(a), together with an LDL-like lipid core. Lp(a) level is mainly controlled by LPA expression, which is associated with atherosclerosis and inhibition of thrombolysis. Additionally, 
$\mathrm{Lp}(\mathrm{a})$ is a structural analogue of plasminogen and can compete with it for fibrin binding, thereby suppressing fibrinolysis. Although high Lp(a) levels were associated with lower risk of major bleeding in the brain in the Copenhagen General Population study [57], a low number of TTTTA repeats was shown to be related to an elevation in the levels of $\mathrm{Lp}(\mathrm{a})$ and to an increased risk of ICH in the Chinese population [58]. The contradictory results require more studies in different ethnic groups, involving larger cohorts, to clarify further.

\subsection{Genetic Variants Related to Inflammation (Table 3)}

Endothelium has functions in the regulation of vascular tone and inflammatory balance. The loss of endothelial-mediated vasodilatation, and the presence of both the inflammatory and prothrombotic states, are the earliest manifestations of vascular damage.

\subsubsection{Methylenetetrahydrofolate Reductase (MTHFR)}

Cytogenetic location: 1p36.22, $20 \mathrm{~kb}$, main risk variant: rs1801133 (chr1:11796321, missense, C>T, p.A222V). The MTHFR plays a role in processing amino acids and converting their homocysteine to methionine. The rs1801133 polymorphism in the MTHFR exon 4 reduces the MTHFR activity and leads to hyperhomocysteinemia [59], a risk factor for atherosclerosis, inflammation, and endothelial dysfunction [60]. The largest of the meta-analyses (16 studies on 1585 cases/3620 controls (Asians) and 243 cases / 447 controls (Caucasians)) [61] reported an association between the MTHFR 677 T variant allele and ICH in both the Asian (in all the inheritance models) and the Caucasian (in the recessive model) populations, with a stronger correlation in the Asian than in the European population.

\subsubsection{Interleukin 6 (IL6)}

Cytogenetic location: 7p15.3, $6 \mathrm{~kb}$, main risk variant (intron variant, upstream variant): rs1800796 (chr7:22726627, G>C). IL-6 is a pleiotropic cytokine which may be a key mediator in the inflammatory response to ICH [62]. It in fact both activates endothelial cells, and induces vascular dysfunction, vascular macrophage accumulation, oxidative stress and increased angiotensin I receptors in vascular smooth muscle. This, in turn, enhances NF-kB activation [63], which leads to increased expression of pro-inflammatory cytokines. The functional promoter of IL-6 in the rs1800796 polymorphism (C allele) was significantly associated with a higher risk of developing ICH in the Japanese population [64]. It is noteworthy that the $\mathrm{C}$ allele is the major allele of rs 1800796 in the Asian population (79\%) but the minor allele in the European population $(<5 \%)$, according to the HapMap database. While this genetic variant may be related to an increased expression of IL-6 [65], a high plasma IL-6 level at hospital admission was considered as an independent predictor of hematoma enlargement [66].

\subsubsection{Tumor Necrosis Factor (TNF)}

Cytogenetic location: 6p21.33, 6 kb, main variants: rs1799964 (chr6:31574531, T>C) $(-1031)$; rs1800629 (chr6:31575254, G>A) (-308); rs1800630 (chr6:31574699, C>A) (-863). TNF- $\alpha$ is one of the main proinflammatory cytokines, and plays a central role in initiating and regulating the inflammatory response. Polymorphisms in the regulatory region result in different TNF- $\alpha$ concentrations. The above three SNPs were shown to be associated with increasing TNF- $\alpha$ expression $[67,68]$. TNF- $\alpha$ induces MMP production, leading to endothelial dysfunction and blood-brain barrier breakdown [69]. While two polymorphisms within the TNF- $\alpha$ promoter, namely rs1799964 and rs1800629, were associated with $\mathrm{DICH}$ in men, the risk of developing DICH was inversely associated with the rs 1800630 polymorphism in the Taiwanese population [70]. In contrast, $-857 \mathrm{C} / \mathrm{T}$ (rs1799724) but not $-308 \mathrm{G} / \mathrm{A}$ was shown to be involved in male ICH susceptibility in a small Korean study [71]. 
Table 2. Variants associated with ICH: lipid metabolism.

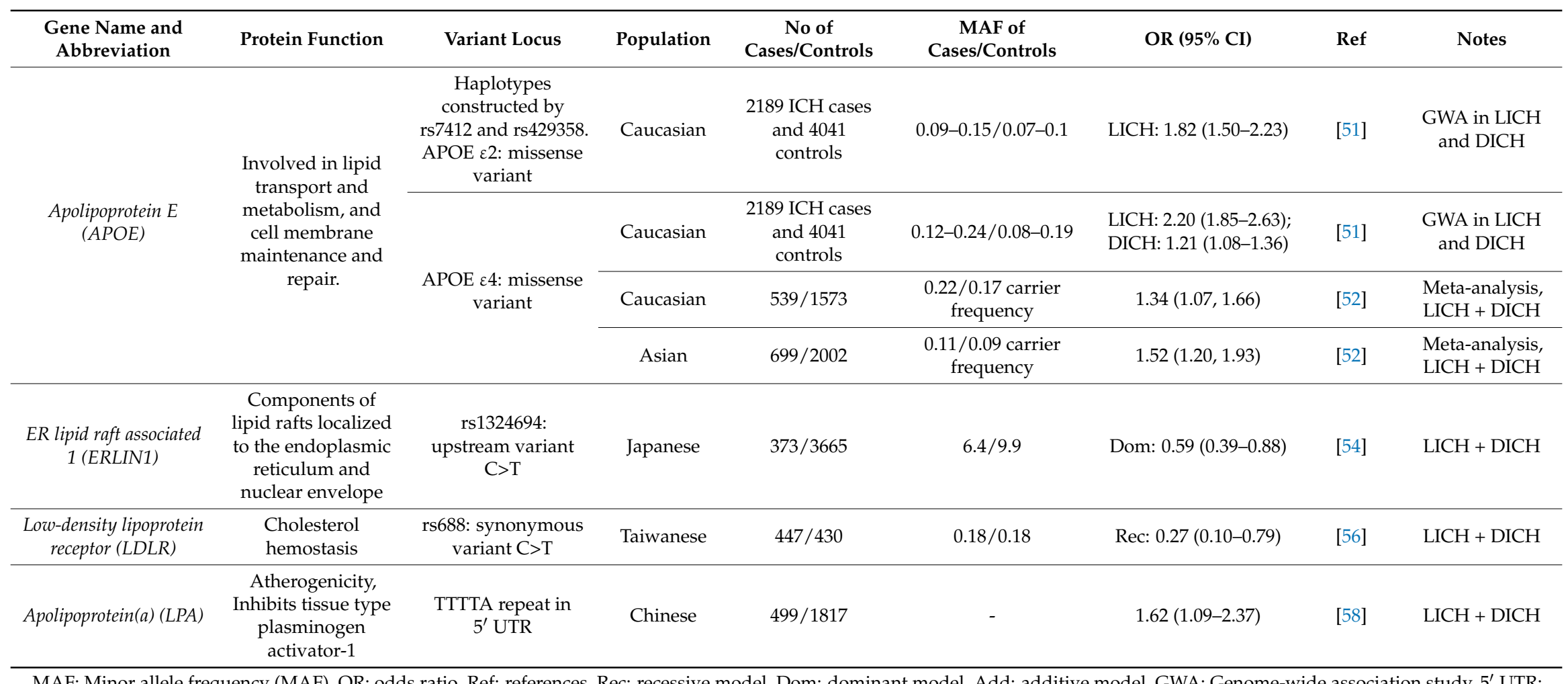

MAF: Minor allele frequency (MAF), OR: odds ratio, Ref: references, Rec: recessive model, Dom: dominant model, Add: additive model, GWA: Genome-wide association study, $5^{\prime}$ UTR: $5^{\prime}$ untranslated region. 


\subsubsection{Trafficking Protein Particle Complex 9 (TRAPPC)}

Cytogenetic location: 6p21.33, 2 kb, main protective variant: rs12679196 (chr8:139800104, intron variant, $\mathrm{C}>\mathrm{T}$ ). The protein encoded by TRAPPC is implicated in vesicular transport, and plays a role in neuronal NF- $\mathrm{kB}$ signaling by both binding the mitogen-activated protein kinase and inhibiting the $\mathrm{K}$ light polypeptide gene enhancer in B-cells, i.e., kinase $\beta$ [72]. Overexpression of TRAPPC potentiates TNF- $\alpha$-induced NF-KB activation, through increased phosphorylation of the IKK complex and its downstream I $\mathrm{K} \mathrm{B} \alpha$ and $\mathrm{p} 65$ substrates [72]. TRAPPC encoded protein is therefore suggested to be an enhancer of the cytokine-induced NF- $\mathrm{kB}$ signaling pathway. In the Japanese population, an intronic polymorphism, namely rs12679196 (C allele), is significantly associated with ICH, while the T allele protects against the disease [54].

\subsubsection{Endoglin (ENG)}

Cytogenetic location: 9q34.11, $39 \mathrm{~kb}$, main risk variant: GGGGGA insertion. The ENG gene encodes a transmembrane glycoprotein, essential for angiogenesis and vascular development, which is predominantly expressed in vascular endothelial cells and is crucial for maintaining vascular integrity [73]. It functions as a co-receptor for transforming growth factor- $\beta$ (TGFB) family members, and it interacts with their signaling serine/threonine kinase receptors [74]. Mutations in ENG were shown to represent a genetic marker of angiogenesis in hereditary hemorrhagic telangiectasia type 1 [75]. Soluble ENG is related to the formation of sporadic brain arteriovenous malformations by acting as a decoy receptor, which results in TGFB signaling inhibition [76]. A study conducted in the United States of America found a homozygous insertion of GGGGGA located 26 bases beyond the $3^{\prime}$ end of exon 7 of $E N G$ to be associated with ICH [77].

\subsubsection{Interferon Epsilon (IFNE)}

Cytogenetic location: 9p21.3, 1 kb, main risk variant: rs2039381 (chr9:21481484, C>T, stop gained, p.Q71Stop). Type I Interferons have major roles in the innate immune responses. In stroke, type I interferons, including IFNE, have a role in the cytotoxic immune pathway to control immune responses in the central nervous system [78]. IFNE is expressed in many tissues, including the brain, coronary smooth muscle endothelial cells, and microvascular endothelial cells [79]. It can be induced by proinflammatory cytokines and regulate the hyaluronic acid-mediated motility receptor which is involved in the formation of cerebral microvessels [80]. In the Korean population, a nonsense polymorphism of IFNE, rs2039381, is associated with ICH [81].

\subsubsection{Transforming Growth Factor Beta 2 Receptor 2 (TGFBR2)}

Cytogenetic location: 3p24.1, 87 kb, main risk variant: rs2228048 (chr3:30672350, synonymous codon, C>T, N389N). TGFB is a cytokine that plays important roles in the development, homeostasis, and tolerance of $\mathrm{T}$ cells [82]. The TGFBR2 is mainly expressed by neurons [83], and a reduction in its signaling results in accelerated age-dependent neurodegeneration [84]. A previous study in the Korean population found an association between the rs2228048 polymorphism and ICH [85]. 
Table 3. Variants associated with ICH: inflammation

\begin{tabular}{|c|c|c|c|c|c|c|c|c|}
\hline $\begin{array}{l}\text { Gene Name and } \\
\text { Abbreviation }\end{array}$ & Protein Function & Variant Locus & Population & $\begin{array}{c}\text { No of } \\
\text { Cases/Controls }\end{array}$ & $\begin{array}{c}\text { MAF of } \\
\text { Cases/Controls }\end{array}$ & OR $(95 \% \mathrm{CI})$ & Ref & Notes \\
\hline \multirow{2}{*}{$\begin{array}{l}\text { Methylenetetrahydrofolate } \\
\text { reductase (MTHFR) }\end{array}$} & \multirow{2}{*}{$\begin{array}{l}\text { Converts homocysteine } \\
\text { to methionine }\end{array}$} & \multirow{2}{*}{$\begin{array}{l}\text { rs } 1801133 \mathrm{C}>\mathrm{T} \\
\text { p.A222V }\end{array}$} & Asian & $1585 / 3620$ & $0.48 / 0.41$ & $1.42(1.19-1.69)$ & [61] & \multirow{2}{*}{$\begin{array}{l}\text { Meta-analysis in } \\
\text { LICH + DICH; }\end{array}$} \\
\hline & & & Caucasian & $243 / 447$ & $0.18 / 0.48$ & Rec: 2.23 (1.06-4.71) & [61] & \\
\hline IL-6 (IL6) & $\begin{array}{l}\text { Proinflammatory } \\
\text { cytokine }\end{array}$ & $\begin{array}{l}\text { rs1800796: intron } \\
\text { variant, } G>C(-572)\end{array}$ & Japanese & $282 / 2010$ & $0.19 / 0.25$ & Rec: $1.6(1.2-2.1)$ & [64] & $\mathrm{LICH}+\mathrm{DICH}$ \\
\hline $\begin{array}{c}\text { Tumor necrosis factor } \\
\text { (TNF) }\end{array}$ & $\begin{array}{l}\text { Proinflammatory } \\
\text { cytokine; regulator of } \\
\text { cell proliferation, lipid } \\
\text { metabolism, apoptosis, } \\
\text { and coagulation }\end{array}$ & $\begin{array}{c}\text { rs1799964: downstream } \\
\text { variant 500B, upstream } \\
\text { variant } 2 \mathrm{~KB} \text { T>C } \\
(-1031) \\
\text { rs1800629: upstream } \\
\text { variant } \mathrm{G}>\mathrm{A} \\
(-308) \\
\text { rs1800630: downstream } \\
\text { variant 500B, upstream } \\
\text { variant } 2 \mathrm{~KB} C>\mathrm{A} \\
(-863)\end{array}$ & Taiwanese & $\begin{array}{l}\text { 177/226 (male); } \\
\text { 177/226 (male); } \\
83 / 142 \text { (female) }\end{array}$ & $\begin{array}{c}\text { 0.19/0.13 (male); } \\
0.15 / 0.09 \text { (male); } \\
0.18 / 0.23 \text { (female) }\end{array}$ & $\begin{array}{l}\text { Add: } 1.9(1.1-3.4) ; \\
\quad 2.6(1.3-5.3) ; \\
0.5(0.2-0.9)\end{array}$ & [70] & $\mathrm{DICH}$ \\
\hline $\begin{array}{l}\text { Trafficking protein } \\
\text { particle complex } 9 \text { gene } \\
\text { (TRAPPC) }\end{array}$ & $\begin{array}{l}\text { Trafficking protein } \\
\text { particle complex } \\
\text { subunit } 9\end{array}$ & $\begin{array}{l}\text { rs12679196: intron } \\
\text { variant } C>T\end{array}$ & Japanese & $376 / 3722$ & $0.18 / 0.21$ & Add: $0.2(0.0-0.6)$ & [54] & $\mathrm{LICH}+\mathrm{DICH}$ \\
\hline Endoglin (ENG) & $\begin{array}{l}\text { Transmembrane } \\
\text { glycoprotein, part of } \\
\text { TGF- } \beta \text { receptor } \\
\text { complex }\end{array}$ & GGGGGA insertion & US & $103 / 202$ & $\begin{array}{c}0.09 / 0.02 \\
\text { (homozygous) }\end{array}$ & $4.8(1.3-21.6)$ & [77] & $\mathrm{LICH}+\mathrm{DICH}$ \\
\hline $\begin{array}{l}\text { Interferon epsilon } \\
\text { (IFNE) }\end{array}$ & $\begin{array}{c}\text { Proinflammatory } \\
\text { cytokines }\end{array}$ & $\begin{array}{l}\text { rs2039381, stop gained } \\
\text { C }>\text { T, p.Q71Stop }\end{array}$ & Korean & $145 / 401$ & $0.22 / 0.15$ & Add: $2.0(1.3-3)$ & [81] & $\mathrm{LICH}+\mathrm{DICH}$ \\
\hline $\begin{array}{l}\text { Transforming growth } \\
\text { factor beta } 2 \text { receptor } 2 \\
\text { (TGFBR2) }\end{array}$ & $\begin{array}{l}\text { Transmembrane protein } \\
\text { for development of T } \\
\text { cells and regulator of } \\
\text { cell proliferation }\end{array}$ & $\begin{array}{l}\text { rs2228048: synonymous } \\
\text { codon } \mathrm{C}>\mathrm{T}, \mathrm{N} 389 \mathrm{~N}\end{array}$ & Korean & $127 / 395$ & $0.28 / 0.19$ & $1.7(1.2-2.4)$ & [85] & $\mathrm{LICH}+\mathrm{DICH}$ \\
\hline
\end{tabular}

MAF: Minor allele frequency (MAF), OR: odds ratio, Ref: references, Rec: recessive model, Dom: dominant model, Add: additive model. 


\subsection{Other Genetic Variants (Table 4)}

A meta-analysis of data from the International Stroke Genetics Consortium (1681 cases, 2261 controls) identified 1q22 to be a susceptibility locus for DICH [86]. Specifically, two genes are found at this locus, the polyamine-modulated factor 1 (PMF1) and the solute carrier family 25-member 44 (SLC25A44). The top-associated variant within this locus was rs2984613, an intron variant of PMF1. In the discovery phase of the meta-analysis, $12 \mathrm{q} 21.1$ was associated with $\mathrm{ICH}$, especially with $\mathrm{LICH}$, while the greatest association with rs 11179580 was seen near the thyrotropin-releasing hormone degrading enzyme gene (TRHDE). However, the latter relation was not found to be significant in the replication phase.

\subsubsection{Polyamine-Modulated Factor 1 (PMF1)}

Cytogenetic location: 1q22, 27 kb, main risk variant: rs2984613 (chr1:156227589, intron variant, $\mathrm{C}>\mathrm{T}$ ). Solute carrier family 25, member 44 (SLC25A44): Cytogenetic location: 1q22, $18 \mathrm{~kb}$. While the PMF1 protein, a nuclear protein regulated by polyamines, is involved in chromosomal alignment and segregation during mitosis [87], it also mediates the transcriptional induction of an acetyltransferase responsible for the rate-limiting enzyme in the catabolic pathway of polyamine metabolism, which has been implicated in breakdown of the blood-brain barrier and regulation of the excite-toxicity after stroke [88,89]. SLC25A44 codes for solute carrier family 25 member 44 that belongs to the SLC 25 family of mitochondrial carrier proteins, and is widely expressed in the central nervous system [90]. However, the pathological link between this protein and ICH is unknown to date.

\subsubsection{Thyrotropin-Releasing Hormone Degrading Enzyme Gene (TRHDE)}

Cytogenetic location: 12q21.1, 579 kb, main risk variant: rs11179580 (chr12:73192799, intron variant, $\mathrm{C}>\mathrm{T}$ ). The thyrotropin-releasing hormone (TRH) is a central neurotransmitter that stimulates hormone secretion from adenohypophyseal cells and is inactivated instead by the TRH-degrading enzyme [91]. The association between rs 11179580 and ICH was discovered in the discovery phase of meta-analysis of six genome-wide association studies in Europeans; however, the result should be explored further given lack of replication confirmation [86].

\subsubsection{Fibrinogen Alpha Chain (FGA)}

Cytogenetic location: 4q31.3, $7 \mathrm{~kb}$, main risk variant: rs6050 (chr4:154586438, missense, T>C, NP_000499.1: p.T331A). Soluble fibrinogen is converted into insoluble fibrin by activated thrombin. The rs6050 polymorphism of $F G A$ causes $\mathrm{f}$ substitution from threonine to alanine and alters the fibrinogen structure, leading to a reduced affinity for degrading enzymes, which increases, in turn, fibrin clot resistance to thrombolytic cleavage [92]. The rs6050 polymorphism was significantly associated with decreased plasma fibrinogen and reduced platelet distribution in white people [93]. This procoagulant FGA polymorphism was found to represent a risk factor of ICH in a Polish and Greek study [94]. Furthermore, haplotypes composed of the ATA (rs1800790 + rs1800787 + rs6050), AA (rs1800790 + rs6050), and TA (rs1800787 + rs6050), however not individual polymorphisms, were shown to contribute to the risk of ICH in the Chinese population as well [95]. 


\subsubsection{Tubulin Beta-1 Chain (TUBB1)}

Cytogenetic location: 20q13.32, 10 kb, main risk variant: rs415064 (chr20:59022916, missense, $\mathrm{G}>\mathrm{C}$, p.Q43P). The TUBB1 is a microtubules component required for optimal platelet assembly and mutations in this gene could cause macrothrombocytopenia [96]. The rs415064 polymorphism in the TUBB1 alters platelet reactivity by modulating platelet function and structure [97]. A study conducted on the Spanish population reported that the rs415064 polymorphism increases the risk of ICH and is associated with an earlier age at onset of ICH [98]. Furthermore, when the rs415064 polymorphism is inherited along with the $-323 \mathrm{I} / \mathrm{D}$ polymorphism on the factor VII gene, the ICH risk increases 20-fold [98].

\subsubsection{WNK Lysine Deficient Protein Kinase 2 (WNK2)}

Cytogenetic location: 9q22.31, 143 kb, main risk variant: rs16936752 (chr9:93301408, intron variant, $\mathrm{T}>\mathrm{G}$ ). The WNK2 encodes a regulator of cell cycle progression. Wnk2 is a serine-threonine kinase which phosphorylates the exogenous substrate of the myelin basic protein, mostly on the serine residues. WNK2 is also involved in the modulation of growth factor-induced cancer cell proliferation [99]. However, no known function is associated with the pathogenesis of ICH to date. The rs 16936752 polymorphism T allele of WNK2 is an intron variant which was reported to increase the risk of ICH in the Japanese population [54].

\subsubsection{Potassium Channel, Subfamily K, Member 17 (KCNK17)}

Cytogenetic location: $6 \mathrm{p} 21.2,15 \mathrm{~kb}$, main protective variant (intron variants): rs12214600 (chr6:39300960, C>T) and rs10947803 (merged into rs9471058, chr6:39302834, C>A). KCNK17 is a member of the 2-pore domain superfamily of background potassium channels. It generates the negative membrane potential, contributes to the resting potential in excitable and non-excitable cells, and may influence cerebral blood vessel dilation. The T carrier of rs12214600 is associated with reduced risk of ICH, whereas the A carrier of rs10947803 increases the risk of ICH in the Chinese population $[100,101]$.

\section{Clinical Implications for ICH Management}

Pharmacogenomics and pharmacogenetics enable clinicians and researchers to implement knowledge in the context of personalized medicine. Knowing gene-drug-disease relationships helps move treatment of disease from bench to bedside [102]. Although there was no report directly addressing pharmacogenomics/pharmacogenetics for $\mathrm{ICH}$, several reports showed genetic variations related to the ICH risks or the treatments involving ICH prevention. Among the reviewed genetic variations, the $A C E$ rs1799752 minor allele displayed significantly different response to captopril in type 2 diabetes mellitus, heart failure, and chronic obstructive pulmonary disease [102,103]. For another example, APOE rs7412 showed that heterozygous allele CT of rs7412 has a 39.9\% lowering of LDL by atorvastatin, compared to a $36.4 \%$ lowering among Caucasians with the common allele CC [104]. Although MTHFR rs1801133 has an impact on clinical drug responses, the effects are mainly on cyclophosphamide and carboplatin in treating cancers $[105,106]$. Additionally, the TNF rs1800629 variant demonstrated different drug responses to TNF-alpha inhibitors in arthritis, psoriatic arthritis, and ankylosing spondylitis $[107,108]$. Whether polymorphisms are associated with different responses to treatments in ICH remains to be explored. 
Table 4. Variants associated with ICH: others.

\begin{tabular}{|c|c|c|c|c|c|c|c|c|}
\hline $\begin{array}{l}\text { Gene Name and } \\
\text { Abbreviation }\end{array}$ & Protein Function & Variant Locus & Population & $\begin{array}{c}\text { No of } \\
\text { Cases/Controls }\end{array}$ & $\begin{array}{c}\text { MAF of } \\
\text { Cases/Controls }\end{array}$ & OR $(95 \% \mathrm{CI})$ & Ref & Notes \\
\hline $\begin{array}{l}\text { Polyamine-modulated } \\
\text { factor } 1 \text { (PMF1) }\end{array}$ & $\begin{array}{c}\text { Required for } \\
\text { chromosome alignment } \\
\text { and segregation, and } \\
\text { kinetochore formation } \\
\text { during mitosis }\end{array}$ & $\begin{array}{l}\text { rs2984613: intron } \\
\text { variant } C>T\end{array}$ & European & $\begin{array}{c}1545 / 1481 \\
664 \mathrm{LICH} \text { and } \\
881 \text { DICH cases }\end{array}$ & $0.31 / 0.31$ & Add: $1.29(1.22-1.46)$ & [86] & $\begin{array}{l}\text { DICH; } \\
\text { Meta-analysis of } \\
\text { GWAs with } \\
\text { replication }\end{array}$ \\
\hline $\begin{array}{l}\text { Solute carrier family } 25, \\
\text { member } 44 \\
\text { (SLC25A44) }\end{array}$ & $\begin{array}{c}\text { Nuclear-encoded } \\
\text { transporters embedded } \\
\text { in the inner } \\
\text { mitochondrial } \\
\text { membrane and other } \\
\text { organelle membranes }\end{array}$ & $\begin{array}{c}\text { Within the } \\
\text { susceptibility locus } \\
\text { 1q22 }\end{array}$ & & & & & & \\
\hline $\begin{array}{l}\text { Thyrotropin- releasing } \\
\text { hormone- degrading } \\
\text { ectoenzyme (TRHDE) }\end{array}$ & $\begin{array}{c}\text { Inactivates } \\
\text { thyrotropin-releasing } \\
\text { hormone }\end{array}$ & $\begin{array}{l}\text { rs11179580: intron } \\
\text { variant } \mathrm{C}>\mathrm{T}\end{array}$ & European & $\begin{array}{c}1545 / 1481 \\
664 \mathrm{LICH} \text { and } \\
881 \text { DICH cases }\end{array}$ & $0.24 / 0.25$ & $\begin{array}{c}\text { Add: } \\
\text { LICH: } 1.56(1.33-1.84) \\
\text { DICH: } 1.25\end{array}$ & [86] & $\begin{array}{l}\mathrm{LICH}>\mathrm{DICH} ; \\
\text { Meta-analysis of } \\
\text { GWAs without } \\
\text { replication }\end{array}$ \\
\hline $\begin{array}{l}\text { Fibrinogen alpha chain } \\
\text { (FGA) }\end{array}$ & $\begin{array}{l}\text { Cleaved to yield } \\
\text { monomers, which, } \\
\text { together with } \\
\text { fibrinogen beta and } \\
\text { gamma, polymerize to } \\
\text { form fibrin matrix }\end{array}$ & $\begin{array}{l}\text { rs6050: missense } \mathrm{T}>\mathrm{C}, \\
\text { p.T331A }\end{array}$ & $\begin{array}{l}\text { Polish and } \\
\text { Greek }\end{array}$ & $503 / 774$ & $0.21 / 0.23$ & Dom: 2.3 (1.1-4.8) & [94] & $\mathrm{LICH}+\mathrm{DICH}$ \\
\hline $\begin{array}{l}\text { Tubulin beta-1 chain } \\
\text { (TUBB1) }\end{array}$ & $\begin{array}{l}\text { Major constituent of } \\
\text { microtubules }\end{array}$ & $\begin{array}{l}\text { rs415064: missense } \\
\text { G>C, p.Q43P }\end{array}$ & Spanish & $259 / 449$ & $0.12 / 0.06$ & $2.36(1.25-4.45)$ & [98] & $\mathrm{LICH}+\mathrm{DICH}$ \\
\hline $\begin{array}{l}\text { WNK lysine deficient } \\
\text { protein kinase } 2 \\
\text { (WNK2) }\end{array}$ & $\begin{array}{l}\text { Serine/threonine } \\
\text { kinase that controls } \\
\text { PAK1, a regulator of } \\
\text { cell motility }\end{array}$ & $\begin{array}{l}\text { rs16936752: intron } \\
\text { variant } T>G\end{array}$ & Japanese & $376 / 3671$ & $0.08 / 0.11$ & Rec: 1.59 \# (1.10-2.38) & [54] & $\mathrm{LICH}+\mathrm{DICH}$ \\
\hline \multirow[b]{2}{*}{ KCNK17 } & \multirow{2}{*}{$\begin{array}{l}\text { potassium channel, } \\
\text { subfamily K, member17 }\end{array}$} & $\begin{array}{l}\text { rs12214600: intron } \\
\text { variant } C>T\end{array}$ & Chinese & $182 / 174$ & $0.10 / 0.17$ & $0.56(0.35-0.90)$ & [100] & $\mathrm{LICH}+\mathrm{DICH}$ \\
\hline & & $\begin{array}{l}\text { rs10947803: (merged } \\
\text { into rs9471058) intron } \\
\text { variant } C>A\end{array}$ & Chinese & $166 / 156$ & $0.42 / 0.34$ & Dom: 1.65 (1.04-2.62) & [101] & $\mathrm{LICH}+\mathrm{DICH}$ \\
\hline
\end{tabular}

MAF: Minor allele frequency (MAF), OR: odds ratio, Ref: references, Rec: recessive model, Dom: dominant model, Add: additive model, GWA: Genome-wide association study. ${ }^{\#}$ The risk allele is $\mathrm{T}$. 


\section{Conclusions}

The majority of the genes associated with ICH only provide small contributions to the risk of developing such a condition. However, the mechanisms behind such associations require further investigation. Additionally, variations in APOE (in multiple ethnicities), PMF1/SLC25A44 (in Europeans), ACE (in Asians), MTHFR (in multiple ethnicities), TRHDE (in Europeans), and COL4A2 (in Europeans) are the most convincing genetic factors related to ICH. Furthermore, although LICH and DICH differ in pathogenesis, many of the above-mentioned studies did not separate the ICH phenotypes. Except for TIMP-1, which locates to the $\mathrm{X}$ chromosome with effects more prominent in males than females, no report with adequate sample number has reported significant gender difference in genetic difference regarding ICH risks. Future replications are required to both confirm their association in multiple ethnicities and to elucidate the roles of these genetic variations in ICH pathogenesis. More importantly, given that both the lifestyle and the medication controls are different among countries, gene-gene and gene-environment interactions should be taken into consideration in the analyses.

Author Contributions: Y.-C.C., K.-H.C.: Writing and Review; C.-M.C.: Review and Editing.

Funding: Chang Gung Medical Research Program [grant numbers CMRPG3C174, CMRPG3E150, and CMRPG3G0962].

Conflicts of Interest: The authors declare no conflict of interest.

\section{References}

1. Benjamin, E.J.; Virani, S.S.; Callaway, C.W.; Chamberlain, A.M.; Chang, A.R.; Cheng, S.; Chiuve, S.E.; Cushman, M.; Delling, F.N.; Deo, R.; et al. Heart Disease and Stroke Statistics-2018 Update: A Report From the American Heart Association. Circulation 2018, 137, e67-e492. [CrossRef] [PubMed]

2. Qureshi, A.I.; Mendelow, A.D.; Hanley, D.F. Intracerebral haemorrhage. Lancet 2009, 373, $1632-1644$. [CrossRef]

3. Hajat, C.; Dundas, R.; Stewart, J.A.; Lawrence, E.; Rudd, A.G.; Howard, R.; Wolfe, C.D. Cerebrovascular risk factors and stroke subtypes: Differences between ethnic groups. Stroke 2001, 32, 37-42. [CrossRef] [PubMed]

4. Kitamura, A.; Nakagawa, Y.; Sato, M.; Iso, H.; Sato, S.; Imano, H.; Kiyama, M.; Okada, T.; Okada, H.; Iida, M.; et al. Proportions of stroke subtypes among men and women $>$ or $=40$ years of age in an urban Japanese city in 1992, 1997, and 2002. Stroke 2006, 37, 1374-1378. [CrossRef] [PubMed]

5. Zhang, L.F.; Yang, J.; Hong, Z.; Yuan, G.G.; Zhou, B.F.; Zhao, L.C.; Huang, Y.N.; Chen, J.; Wu, Y.F. Proportion of different subtypes of stroke in China. Stroke 2003, 34, 2091-2096. [CrossRef] [PubMed]

6. Hsieh, F.I.; Lien, L.M.; Chen, S.T.; Bai, C.H.; Sun, M.C.; Tseng, H.P.; Chen, Y.W.; Chen, C.H.; Jeng, J.S.; Tsai, S.Y.; et al. Get With the Guidelines-Stroke performance indicators: Surveillance of stroke care in the Taiwan Stroke Registry: Get With the Guidelines-Stroke in Taiwan. Circulation 2010, 122, 1116-1123. [CrossRef] [PubMed]

7. Van Asch, C.J.; Luitse, M.J.; Rinkel, G.J.; van der Tweel, I.; Algra, A.; Klijn, C.J. Incidence, case fatality, and functional outcome of intracerebral haemorrhage over time, according to age, sex, and ethnic origin: A systematic review and meta-analysis. Lancet Neurol. 2010, 9, 167-176. [CrossRef]

8. Qureshi, A.I.; Tuhrim, S.; Broderick, J.P.; Batjer, H.H.; Hondo, H.; Hanley, D.F. Spontaneous intracerebral hemorrhage. N. Engl. J. Med. 2001, 344, 1450-1460. [CrossRef]

9. Fisher, C.M. Pathological observations in hypertensive cerebral hemorrhage. J. Neuropathol. Exp. Neurol. 1971, 30, 536-550. [CrossRef]

10. Krishnan, K.; Beishon, L.; Berge, E.; Christensen, H.; Dineen, R.A.; Ozturk, S.; Sprigg, N.; Wardlaw, J.M.; Bath, P.M. Relationship between race and outcome in Asian, Black, and Caucasian patients with spontaneous intracerebral hemorrhage: Data from the Virtual International Stroke Trials Archive and Efficacy of Nitric Oxide in Stroke trial. Int. J. Stroke 2018, 13, 362-373. [CrossRef]

11. Flaherty, M.L.; Woo, D.; Haverbusch, M.; Sekar, P.; Khoury, J.; Sauerbeck, L.; Moomaw, C.J.; Schneider, A.; Kissela, B.; Kleindorfer, D.; et al. Racial variations in location and risk of intracerebral hemorrhage. Stroke 2005, 36, 934-937. [CrossRef] [PubMed] 
12. Galati, A.; King, S.L.; Nakagawa, K. Gender Disparities among Intracerebral Hemorrhage Patients from a Multi-ethnic Population. Hawaii. J. Med. Public Health 2015, 74, 12-15. [PubMed]

13. Ho, W.M.; Chen, C.M.; Lee, Y.S.; Chang, K.H.; Chen, H.W.; Chen, S.T.; Chen, Y.C. Association of MMP-9 Haplotypes and TIMP-1 Polymorphism with Spontaneous Deep Intracerebral Hemorrhage in the Taiwan Population. PLoS ONE 2015, 10, e0125397. [CrossRef] [PubMed]

14. Chen, Y.C.; Ho, W.M.; Lee, Y.S.; Chen, H.W.; Chen, C.M. Polymorphisms in the Promoters of the MMP-2 and TIMP-2 Genes Are Associated with Spontaneous Deep Intracerebral Hemorrhage in the Taiwan Population. PLoS ONE 2015, 10, e0142482. [CrossRef] [PubMed]

15. Chen, Y.C.; Lee-Chen, G.J.; Wu, Y.R.; Hu, F.J.; Wu, H.C.; Kuo, H.C.; Chu, C.C.; Ryu, S.J.; Chen, S.T.; Chen, C.M. Analyses of interaction effect between apolipoprotein E polymorphism and alcohol use as well as cholesterol concentrations on spontaneous deep intracerebral hemorrhage in the Taiwan population. Clin. Chim. Acta 2009, 408, 128-132. [CrossRef] [PubMed]

16. Chen, Y.C.; Wu, Y.R.; Hsu, W.C.; Chen, C.M.; Lee, T.H.; Chen, S.T. Basal Ganglia-thalamic hemorrhage in young adults: A hospital-based study. Cerebrovasc. Dis. 2006, 22, 33-39. [CrossRef]

17. Ariesen, M.J.; Claus, S.P.; Rinkel, G.J.; Algra, A. Risk factors for intracerebral hemorrhage in the general population: A systematic review. Stroke 2003, 34, 2060-2065. [CrossRef]

18. Woo, D.; Sauerbeck, L.R.; Kissela, B.M.; Khoury, J.C.; Szaflarski, J.P.; Gebel, J.; Shukla, R.; Pancioli, A.M.; Jauch, E.C.; Menon, A.G.; et al. Genetic and environmental risk factors for intracerebral hemorrhage: Preliminary results of a population-based study. Stroke 2002, 33, 1190-1195. [CrossRef]

19. Federico, A.; Bianchi, S.; Dotti, M.T. The spectrum of mutations for CADASIL diagnosis. Neurol. Sci. 2005, 26, 117-124. [CrossRef]

20. Battistini, S.; Rocchi, R.; Cerase, A.; Citterio, A.; Tassi, L.; Lando, G.; Patrosso, M.C.; Galli, R.; Brunori, P.; Sgro, D.L.; et al. Clinical, magnetic resonance imaging, and genetic study of 5 Italian families with cerebral cavernous malformation. Arch. Neurol. 2007, 64, 843-848. [CrossRef]

21. Devan, W.J.; Falcone, G.J.; Anderson, C.D.; Jagiella, J.M.; Schmidt, H.; Hansen, B.M.; Jimenez-Conde, J.; Giralt-Steinhauer, E.; Cuadrado-Godia, E.; Soriano, C.; et al. Heritability estimates identify a substantial genetic contribution to risk and outcome of intracerebral hemorrhage. Stroke 2013, 44, 1578-1583. [CrossRef] [PubMed]

22. Carpenter, A.M.; Singh, I.P.; Gandhi, C.D.; Prestigiacomo, C.J. Genetic risk factors for spontaneous intracerebral haemorrhage. Nat. Rev. Neurol. 2016, 12, 40-49. [CrossRef] [PubMed]

23. Falcone, G.J.; Woo, D. Genetics of Spontaneous Intracerebral Hemorrhage. Stroke 2017, 48, 3420-3424. [CrossRef] [PubMed]

24. He, Q.; Fan, C.; Yu, M.; Wallar, G.; Zhang, Z.F.; Wang, L.; Zhang, X.; Hu, R. Associations of ACE gene insertion/deletion polymorphism, ACE activity, and ACE mRNA expression with hypertension in a Chinese population. PLoS ONE 2013, 8, e75870. [CrossRef] [PubMed]

25. Kumar, A.; Prasad, K.; Vivekanandhan, S.; Srivastava, A.; Goswami, S.; Srivastava, M.V.; Tripathi, M. Association between angiotensin converting enzyme gene insertion/deletion polymorphism and intracerebral haemorrhage in North Indian population: A case control study and meta-analysis. Neurol. Sci. 2014, 35, 1983-1990. [CrossRef] [PubMed]

26. Sun, Y.; Liu, Y.; Watts, L.T.; Sun, Q.; Zhong, Z.; Yang, G.Y.; Bian, L. Genetic Associations of Angiotensin-Converting Enzyme with Primary Intracerebral Hemorrhage: A Meta-analysis. PLoS ONE 2013, 8, e67402. [CrossRef]

27. Chen, C.M.; Chen, Y.C.; Wu, Y.R.; Hu, F.J.; Lyu, R.K.; Chang, H.S.; Ro, L.S.; Hsu, W.C.; Chen, S.T.; Lee-Chen, G.J. Angiotensin-converting enzyme polymorphisms and risk of spontaneous deep intracranial hemorrhage in Taiwan. Eur. J. Neurol. 2008, 15, 1206-1211. [CrossRef]

28. Slowik, A.; Turaj, W.; Dziedzic, T.; Haefele, A.; Pera, J.; Malecki, M.T.; Glodzik-Sobanska, L.; Szermer, P.; Figlewicz, D.A.; Szczudlik, A. DD genotype of ACE gene is a risk factor for intracerebral hemorrhage. Neurology 2004, 63, 359-361. [CrossRef]

29. Lee, Y.H.; Choi, S.J.; Ji, J.D.; Song, G.G. Associations between the angiotensin-converting enzyme insertion/deletion polymorphism and susceptibility to vasculitis: A meta-analysis. J. Renin Angiotensin Aldosterone Syst. 2012, 13, 196-201. [CrossRef]

30. Heeneman, S.; Sluimer, J.C.; Daemen, M.J. Angiotensin-converting enzyme and vascular remodeling. Circ. Res. 2007, 101, 441-454. [CrossRef] 
31. Elkins, J.S.; Douglas, V.C.; Johnston, S.C. Alzheimer disease risk and genetic variation in ACE: A meta-analysis. Neurology 2004, 62, 363-368. [CrossRef] [PubMed]

32. Catto, A.; Carter, A.M.; Barrett, J.H.; Stickland, M.; Bamford, J.; Davies, J.A.; Grant, P.J. Angiotensin-converting enzyme insertion/deletion polymorphism and cerebrovascular disease. Stroke 1996, 27, 435-440. [CrossRef] [PubMed]

33. Rannikmae, K.; Davies, G.; Thomson, P.A.; Bevan, S.; Devan, W.J.; Falcone, G.J.; Traylor, M.; Anderson, C.D.; Battey, T.W.; Radmanesh, F.; et al. Common variation in COL4A1/COL4A2 is associated with sporadic cerebral small vessel disease. Neurology 2015, 84, 918-926. [CrossRef] [PubMed]

34. Wang, H.-X.; Yang, Q.-D.; Liu, B.-Q.; Zhang, L.; Ma, M.-M.; Hu, Z.-Y.; Xia, J.; Xu, H.-W.; Du, X.-P. TIMP-1 polymorphisms in a Chinese Han population with intracerebral hemorrhage. Int. J. Neurosci. 2014, 124, 61-67. [CrossRef] [PubMed]

35. Reuter, B.; Bugert, P.; Stroick, M.; Bukow, S.; Griebe, M.; Hennerici, M.G.; Fatar, M. TIMP-2 gene polymorphism is associated with intracerebral hemorrhage. Cerebrovasc. Dis. 2009, 28, 558-563. [CrossRef] [PubMed]

36. Sessa, M. Intracerebral hemorrhage and hypertension. Neurol. Sci. 2008, 29, 258-259. [CrossRef] [PubMed]

37. Jeanne, M.; Labelle-Dumais, C.; Jorgensen, J.; Kauffman, W.B.; Mancini, G.M.; Favor, J.; Valant, V.; Greenberg, S.M.; Rosand, J.; Gould, D.B. COL4A2 mutations impair COL4A1 and COL4A2 secretion and cause hemorrhagic stroke. Am. J. Hum. Genet. 2012, 90, 91-101. [CrossRef] [PubMed]

38. Weng, Y.C.; Sonni, A.; Labelle-Dumais, C.; de Leau, M.; Kauffman, W.B.; Jeanne, M.; Biffi, A.; Greenberg, S.M.; Rosand, J.; Gould, D.B. COL4A1 mutations in patients with sporadic late-onset intracerebral hemorrhage. Ann. Neurol. 2012, 71, 470-477. [CrossRef]

39. Malemud, C.J. Matrix metalloproteinases (MMPs) in health and disease: An overview. Front. Biosci. 2006, 11, 1696-1701. [CrossRef]

40. Chang, J.J.; Emanuel, B.A.; Mack, W.J.; Tsivgoulis, G.; Alexandrov, A.V. Matrix Metalloproteinase-9: Dual Role and Temporal Profile in Intracerebral Hemorrhage. J. Stroke Cerebrovasc. Dis. 2014, 23, 2498-2505. [CrossRef]

41. Newby, A.C. Dual role of matrix metalloproteinases (matrixins) in intimal thickening and atherosclerotic plaque rupture. Physiol. Rev. 2005, 85, 1-31. [CrossRef] [PubMed]

42. Luttun, A.; Lutgens, E.; Manderveld, A.; Maris, K.; Collen, D.; Carmeliet, P.; Moons, L. Loss of matrix metalloproteinase- 9 or matrix metalloproteinase-12 protects apolipoprotein E-deficient mice against atherosclerotic media destruction but differentially affects plaque growth. Circulation 2004, 109, 1408-1414. [CrossRef] [PubMed]

43. Florczak-Rzepka, M.; Grond-Ginsbach, C.; Montaner, J.; Steiner, T. Matrix metalloproteinases in human spontaneous intracerebral hemorrhage: An update. Cerebrovasc. Dis. 2012, 34, 249-262. [CrossRef] [PubMed]

44. Mun-Bryce, S.; Rosenberg, G.A. Matrix metalloproteinases in cerebrovascular disease. J. Cereb. Blood Flow Metab. 1998, 18, 1163-1172. [CrossRef] [PubMed]

45. Wang, J.; Tsirka, S.E. Neuroprotection by inhibition of matrix metalloproteinases in a mouse model of intracerebral haemorrhage. Brain 2005, 128, 1622-1633. [CrossRef]

46. Aoki, T.; Kataoka, H.; Moriwaki, T.; Nozaki, K.; Hashimoto, N. Role of TIMP-1 and TIMP-2 in the progression of cerebral aneurysms. Stroke 2007, 38, 2337-2345. [CrossRef]

47. Sing, C.F.; Davignon, J. Role of the apolipoprotein E polymorphism in determining normal plasma lipid and lipoprotein variation. Am. J. Hum. Genet. 1985, 37, 268-285.

48. Poirier, J. Apolipoprotein E in animal models of CNS injury and in Alzheimer's disease. Trends. Neurosci. 1994, 17, 525-530. [CrossRef]

49. Yamada, M. Cerebral amyloid angiopathy: Emerging concepts. J. Stroke 2015, 17, 17-30. [CrossRef]

50. Tzourio, C.; Arima, H.; Harrap, S.; Anderson, C.; Godin, O.; Woodward, M.; Neal, B.; Bousser, M.G.; Chalmers, J.; Cambien, F.; et al. APOE genotype, ethnicity, and the risk of cerebral hemorrhage. Neurology 2008, 70, 1322-1328. [CrossRef]

51. Biffi, A.; Sonni, A.; Anderson, C.D.; Kissela, B.; Jagiella, J.M.; Schmidt, H.; Jimenez-Conde, J.; Hansen, B.M.; Fernandez-Cadenas, I.; Cortellini, L.; et al. Variants at APOE influence risk of deep and lobar intracerebral hemorrhage. Ann. Neurol. 2010, 68, 934-943. [CrossRef] [PubMed] 
52. Zhang, R.; Wang, X.; Tang, Z.; Liu, J.; Yang, S.; Zhang, Y.; Wei, Y.; Luo, W.; Wang, J.; Li, J.; et al. Apolipoprotein E gene polymorphism and the risk of intracerebral hemorrhage: A meta-analysis of epidemiologic studies. Lipids Health Dis. 2014, 13, 47. [CrossRef] [PubMed]

53. Rannikmae, K.; Samarasekera, N.; Martinez-Gonzalez, N.A.; Al-Shahi Salman, R.; Sudlow, C.L. Genetics of cerebral amyloid angiopathy: Systematic review and meta-analysis. J. Neurol. Neurosurg. Psychiatry 2013, 84, 901-908. [CrossRef] [PubMed]

54. Yoshida, T.; Kato, K.; Yokoi, K.; Oguri, M.; Watanabe, S.; Metoki, N.; Yoshida, H.; Satoh, K.; Aoyagi, Y.; Nozawa, Y.; et al. Association of genetic variants with hemorrhagic stroke in Japanese individuals. Int. J. Mol. Med. 2010, 25, 649-656. [PubMed]

55. Gao, F.; Ihn, H.E.; Medina, M.W.; Krauss, R.M. A common polymorphism in the LDL receptor gene has multiple effects on LDL receptor function. Hum. Mol. Genet. 2013, 22, 1424-1431. [CrossRef] [PubMed]

56. Lee, J.D.; Hsiao, K.M.; Lee, T.H.; Kuo, Y.W.; Huang, Y.C.; Hsu, H.L.; Lin, Y.H.; Wu, C.Y.; Lee, M.; Yang, H.T.; et al. Genetic polymorphism of LDLR (rs688) is associated with primary intracerebral hemorrhage. Curr. Neurovasc. Res. 2014, 11, 10-15. [CrossRef]

57. Langsted, A.; Kamstrup, P.R.; Nordestgaard, B.G. High Lipoprotein(a) and Low Risk of Major Bleeding in Brain and Airways in the General Population: A Mendelian Randomization Study. Clin. Chem. 2017, 63, 1714-1723. [CrossRef]

58. Sun, L.; Li, Z.; Zhang, H.; Ma, A.; Liao, Y.; Wang, D.; Zhao, B.; Zhu, Z.; Zhao, J.; Zhang, Z.; et al. Pentanucleotide TTTTA repeat polymorphism of apolipoprotein(a) gene and plasma lipoprotein(a) are associated with ischemic and hemorrhagic stroke in Chinese: A multicenter case-control study in China. Stroke 2003, 34, 1617-1622. [CrossRef]

59. Ogino, S.; Wilson, R.B. Genotype and haplotype distributions of MTHFR677C $>$ T and 1298A $>$ C single nucleotide polymorphisms: A meta-analysis. J. Hum. Genet. 2003, 48, 1-7. [CrossRef]

60. Lai, W.K.; Kan, M.Y. Homocysteine-Induced Endothelial Dysfunction. Ann. Nutr. Metab. 2015, 67, 1-12. [CrossRef]

61. Gao, S.; Li, H.; Xiao, H.; Yao, G.; Shi, Y.; Wang, Y.; Zhou, X.; Yu, H. Association of MTHFR 677T variant allele with risk of intracerebral haemorrhage: A meta-analysis. J. Neurol. Sci. 2012, 323, 40-45. [CrossRef] [PubMed]

62. Suzuki, S.; Tanaka, K.; Suzuki, N. Ambivalent Aspects of Interleukin-6 in Cerebral Ischemia: Inflammatory versus Neurotrophic Aspects. J. Cereb. Blood Flow Metab. 2008, 29, 464-479. [CrossRef] [PubMed]

63. Sprague, A.H.; Khalil, R.A. Inflammatory Cytokines in Vascular Dysfunction and Vascular Disease. Biochem. Pharmacol. 2009, 78, 539-552. [CrossRef] [PubMed]

64. Yamada, Y.; Metoki, N.; Yoshida, H.; Satoh, K.; Ichihara, S.; Kato, K.; Kameyama, T.; Yokoi, K.; Matsuo, H.; Segawa, T.; et al. Genetic risk for ischemic and hemorrhagic stroke. Arterioscler. Thromb. Vasc. Biol. 2006, 26, 1920-1925. [CrossRef] [PubMed]

65. Fishman, D.; Faulds, G.; Jeffery, R.; Mohamed-Ali, V.; Yudkin, J.S.; Humphries, S.; Woo, P. The effect of novel polymorphisms in the interleukin-6 (IL-6) gene on IL-6 transcription and plasma IL-6 levels, and an association with systemic-onset juvenile chronic arthritis. J. Clin. Investig. 1998, 102, 1369-1376. [CrossRef] [PubMed]

66. Silva, Y.; Leira, R.; Tejada, J.; Lainez, J.M.; Castillo, J.; Davalos, A.; Stroke Project, Cerebrovascular Diseases Group of the Spanish Neurological Society. Molecular signatures of vascular injury are associated with early growth of intracerebral hemorrhage. Stroke 2005, 36, 86-91. [CrossRef] [PubMed]

67. Wilson, A.G.; Symons, J.A.; McDowell, T.L.; McDevitt, H.O.; Duff, G.W. Effects of a polymorphism in the human tumor necrosis factor alpha promoter on transcriptional activation. Proc. Natl. Acad. Sci. USA 1997, 94, 3195-3199. [CrossRef]

68. Higuchi, T.; Seki, N.; Kamizono, S.; Yamada, A.; Kimura, A.; Kato, H.; Itoh, K. Polymorphism of the $5^{\prime}$-flanking region of the human tumor necrosis factor (TNF)-alpha gene in Japanese. Tissue Antigens 1998, 51, 605-612. [CrossRef]

69. Tuttolomondo, A.; Pecoraro, R.; Pinto, A. Studies of selective TNF inhibitors in the treatment of brain injury from stroke and trauma: A review of the evidence to date. Drug Des. Dev. Ther. 2014, 8, 2221-2239. [CrossRef]

70. Chen, Y.-C.; Hu, F.-J.; Chen, P.; Wu, Y.-R.; Wu, H.-C.; Chen, S.-T.; Lee-Chen, G.-J.; Chen, C.-M. Association of TNF- $\alpha$ gene with spontaneous deep intracerebral hemorrhage in the Taiwan population: A case control study. BMC Neurol. 2010, 10, 41. [CrossRef] 
71. Park, H.J.; Kim, S.K.; Park, H.K.; Chung, J.H. Association of promoter polymorphism -857C/T (rs1799724) in tumor necrosis factor gene with intracerebral hemorrhage in Korean males. Neurol. Res. 2017, 39, 90-95. [CrossRef] [PubMed]

72. Hu, W.-H.; Pendergast, J.S.; Mo, X.-M.; Brambilla, R.; Bracchi-Ricard, V.; Li, F.; Walters, W.M.; Blits, B.; He, L.; Schaal, S.M.; et al. NIBP, a Novel NIK and IKK $\beta$-binding Protein That Enhances NF-kB Activation. J. Biol. Chem. 2005, 280, 29233-29241. [CrossRef] [PubMed]

73. Gougos, A.; Letarte, M. Identification of a human endothelial cell antigen with monoclonal antibody 44G4 produced against a pre-B leukemic cell line. J. Immunol. 1988, 141, 1925-1933. [PubMed]

74. Barbara, N.P.; Wrana, J.L.; Letarte, M. Endoglin Is an Accessory Protein That Interacts with the Signaling Receptor Complex of Multiple Members of the Transforming Growth Factor- $\beta$ Superfamily. J. Biol. Chem. 1999, 274, 584-594. [CrossRef] [PubMed]

75. McAllister, K.A.; Grogg, K.M.; Johnson, D.W.; Gallione, C.J.; Baldwin, M.A.; Jackson, C.E.; Helmbold, E.A.; Markel, D.S.; McKinnon, W.C.; Murrel, J.; et al. Endoglin, a TGF- $\beta$ binding protein of endothelial cells, is the gene for hereditary haemorrhagic telangiectasia type 1. Nat. Genet. 1994, 8, 345. [CrossRef] [PubMed]

76. Chen, Y.; Hao, Q.; Kim, H.; Su, H.; Letarte, M.; Karumanchi, S.A.; Lawton, M.T.; Barbaro, N.M.; Yang, G.Y.; Young, W.L. Soluble endoglin modulates aberrant cerebral vascular remodeling. Ann. Neurol. 2009, 66, $19-27$. [CrossRef] [PubMed]

77. Alberts, M.J.; Davis, J.P.; Graffagnino, C.; McClenny, C.; Delong, D.; Granger, C.; Herbstreith, M.H.; Boteva, K.; Marchuk, D.A.; Roses, A.D. Endoglin gene polymorphism as a risk factor for sporadic intracerebral hemorrhage. Ann. Neurol. 1997, 41, 683-686. [CrossRef] [PubMed]

78. Nayak, D.; Johnson, K.R.; Heydari, S.; Roth, T.L.; Zinselmeyer, B.H.; McGavern, D.B. Type I interferon programs innate myeloid dynamics and gene expression in the virally infected nervous system. PLoS Pathog. 2013, 9, e1003395. [CrossRef]

79. Pestka, S.; Krause, C.D.; Walter, M.R. Interferons, interferon-like cytokines, and their receptors. Immunol. Rev. 2004, 202, 8-32. [CrossRef]

80. Lokeshwar, V.B.; Selzer, M.G. Differences in hyaluronic acid-mediated functions and signaling in arterial, microvessel and vein-derived human endothelial cells. J. Biol. Chem. 2000, 275, 27641-27649. [CrossRef]

81. Kim, S.K.; Park, H.J.; Kim, J.W.; Chung, J.-H.; Yoo, S.D.; Kim, D.H.; Yun, D.H.; Kim, H.-S. T Allele of nonsense polymorphism (rs2039381, Gln71Stop) of interferon- $\varepsilon$ is a risk factor for the development of intracerebral hemorrhage. Hum. Immunol. 2014, 75, 88-90. [CrossRef] [PubMed]

82. Travis, M.A.; Sheppard, D. TGF- $\beta$ Activation and Function in Immunity. Annu. Rev. Immunol. 2014, 32, 51-82. [CrossRef] [PubMed]

83. Yi, J.J.; Barnes, A.P.; Hand, R.; Polleux, F.; Ehlers, M.D. TGF- $\beta$ Signaling Specifies Axons During Brain Development. Cell 2010, 142, 144-157. [CrossRef] [PubMed]

84. Tesseur, I.; Zou, K.; Esposito, L.; Bard, F.; Berber, E.; Can, J.V.; Lin, A.H.; Crews, L.; Tremblay, P.; Mathews, P.; et al. Deficiency in neuronal TGF- $\beta$ signaling promotes neurodegeneration and Alzheimer's pathology. J. Clin. Investig. 2006, 116, 3060-3069. [CrossRef] [PubMed]

85. Lim, Y.H.; Jeong, Y.S.; Kim, S.K.; Kim, D.H.; Yun, D.H.; Yoo, SD.; Kim, H.S.; Baik, H.H. Association between TGFBR2 gene polymorphism (rs2228048, Asn389Asn) and intracerebral hemorrhage in Korean population. Immunol. Investig. 2011, 40, 569-580. [CrossRef] [PubMed]

86. Woo, D.; Falcone, G.J.; Devan, W.J.; Brown, W.M.; Biffi, A.; Howard, T.D.; Anderson, C.D.; Brouwers, H.B.; Valant, V.; Battey, T.W.; et al. Meta-analysis of genome-wide association studies identifies 1q22 as a susceptibility locus for intracerebral hemorrhage. Am. J. Hum. Genet. 2014, 94, 511-521. [CrossRef] [PubMed]

87. Wang, Y.; Devereux, W.; Stewart, T.M.; Casero, R.A., Jr. Characterization of the interaction between the transcription factors human polyamine modulated factor (PMF-1) and NF-E2-related factor 2 (Nrf-2) in the transcriptional regulation of the spermidine/spermine N1-acetyltransferase (SSAT) gene. Biochem. J. 2001, 355, 45-49. [CrossRef]

88. Georgiev, D.; Taniura, H.; Kambe, Y.; Takarada, T.; Yoneda, Y. A critical importance of polyamine site in NMDA receptors for neurite outgrowth and fasciculation at early stages of P19 neuronal differentiation. Exp. Cell Res. 2008, 314, 2603-2617. [CrossRef] 
89. Koenig, H.; Goldstone, A.D.; Lu, C.Y. Blood-brain barrier breakdown in cold-injured brain is linked to a biphasic stimulation of ornithine decarboxylase activity and polyamine synthesis: Both are coordinately inhibited by verapamil, dexamethasone, and aspirin. J. Neurochem. 1989, 52, 101-109. [CrossRef]

90. Haitina, T.; Lindblom, J.; Renstrom, T.; Fredriksson, R. Fourteen novel human members of mitochondrial solute carrier family 25 (SLC25) widely expressed in the central nervous system. Genomics 2006, 88, 779-790. [CrossRef]

91. Schomburg, L.; Turwitt, S.; Prescher, G.; Lohmann, D.; Horsthemke, B.; Bauer, K. Human TRH-degrading ectoenzyme cDNA cloning, functional expression, genomic structure and chromosomal assignment. Eur. J. Biochem. 1999, 265, 415-422. [CrossRef] [PubMed]

92. Standeven, K.F.; Grant, P.J.; Carter, A.M.; Scheiner, T.; Weisel, J.W.; Ariens, R.A. Functional analysis of the fibrinogen Aalpha Thr312Ala polymorphism: Effects on fibrin structure and function. Circulation 2003, 107, 2326-2330. [CrossRef] [PubMed]

93. Jeff, J.M.; Brown-Gentry, K.; Crawford, D.C. Replication and characterisation of genetic variants in the fibrinogen gene cluster with plasma fibrinogen levels and haematological traits in the Third National Health and Nutrition Examination Survey. Thromb. Haemost. 2012, 107, 458-467. [CrossRef] [PubMed]

94. Jagiella, J.; Dardiotis, E.; Gasowski, J.; Pera, J.; Dziedzic, T.; Klimkowicz-Mrowiec, A.; Golenia, A.; Wnuk, M.; Fountas, K.; Paterakis, K.; et al. The FGA Thr312Ala polymorphism and risk of intracerebral haemorrhage in Polish and Greek populations. Neurol. Neurochir. Polska 2014, 48, 105-110. [PubMed]

95. Zeng, Y.; Zhang, L.; Hu, Z.; Yang, Q.; Ma, M.; Liu, B.; Xia, J.; Xu, H.; Liu, Y.; Du, X. Fibrinogen polymorphisms associated with sporadic cerebral hemorrhage in a Chinese population. J. Clin. Neurosci. 2012, 19, 753-756. [CrossRef] [PubMed]

96. Kunishima, S.; Kobayashi, R.; Itoh, T.J.; Hamaguchi, M.; Saito, H. Mutation of the beta1-tubulin gene associated with congenital macrothrombocytopenia affecting microtubule assembly. Blood 2009, 113, 458-461. [CrossRef] [PubMed]

97. Freson, K.; De Vos, R.; Wittevrongel, C.; Thys, C.; Defoor, J.; Vanhees, L.; Vermylen, J.; Peerlinck, K.; Van Geet, C. The TUBB1 Q43P functional polymorphism reduces the risk of cardiovascular disease in men by modulating platelet function and structure. Blood 2005, 106, 2356-2362. [CrossRef]

98. Navarro-Nunez, L.; Lozano, M.L.; Rivera, J.; Corral, J.; Roldan, V.; Gonzalez-Conejero, R.; Iniesta, J.A.; Montaner, J.; Vicente, V.; Martinez, C. The association of the beta1-tubulin Q43P polymorphism with intracerebral hemorrhage in men. Haematologica 2007, 92, 513-518. [CrossRef]

99. Moniz, S.; Verissimo, F.; Matos, P.; Brazao, R.; Silva, E.; Kotelevets, L.; Chastre, E.; Gespach, C.; Jordan, P. Protein kinase WNK2 inhibits cell proliferation by negatively modulating the activation of MEK1/ERK1/2. Oncogene 2007, 26, 6071-6081. [CrossRef]

100. He, L.; Ma, Q.; Wang, Y.; Liu, X.; Yuan, Y.; Zhang, Y.; Ou, W.; Liu, L.; Tan, X.; Wang, X. Association of variants in KCNK17 gene with ischemic stroke and cerebral hemorrhage in a Chinese population. J. Stroke Cerebrovasc. Dis. 2014, 23, 2322-2327. [CrossRef]

101. Ma, Q.; Wang, Y.; Shen, Y.; Liu, X.; Zhu, X.; Zhang, H.; Liu, L.; Tan, X.; Wang, L.; Wang, X. The rs10947803 SNP of KCNK17 is associated with cerebral hemorrhage but not ischemic stroke in a Chinese population. Neurosci. Lett. 2013, 539, 82-85. [CrossRef] [PubMed]

102. Whirl-Carrillo, M.; McDonagh, E.M.; Hebert, J.M.; Gong, L.; Sangkuhl, K.; Thorn, C.F.; Altman, R.B.; Klein, T.E. Pharmacogenomics knowledge for personalized medicine. Clin. Pharmacol. Ther. 2012, 92, 414-417. [CrossRef] [PubMed]

103. Mizuiri, S.; Hemmi, H.; Inoue, A.; Takano, M.; Kadomatsu, S.; Tanimoto, H.; Tanegashima, M.; Hayashi, I.; Fushimi, T.; Hasegawa, A. Renal hemodynamic changes induced by captopril and angiotensin-converting enzyme gene polymorphism. Nephron 1997, 75, 310-314. [CrossRef] [PubMed]

104. Thompson, J.F.; Man, M.; Johnson, K.J.; Wood, L.S.; Lira, M.E.; Lloyd, D.B.; Banerjee, P.; Milos, P.M.; Myrand, S.P.; Paulauskis, J.; et al. An association study of 43 SNPs in 16 candidate genes with atorvastatin response. Pharmacogenomics J. 2005, 5, 352. [CrossRef] [PubMed]

105. Cui, L.H.; Yu, Z.; Zhang, T.T.; Shin, M.H.; Kim, H.N.; Choi, J.S. Influence of polymorphisms in MTHFR 677 C $->$ T, TYMS 3R $\rightarrow$ 2R and MTR 2756 A $\rightarrow$ G on NSCLC risk and response to platinum-based chemotherapy in advanced NSCLC. Pharmacogenomics 2011, 12, 797-808. [CrossRef] [PubMed] 
106. Henriquez-Hernandez, L.A.; Murias-Rosales, A.; Gonzalez-Hernandez, A.; de Leon, A.C.; Diaz-Chico, N.; Fernandez-Perez, L. Distribution of TYMS, MTHFR, p53 and MDR1 gene polymorphisms in patients with breast cancer treated with neoadjuvant chemotherapy. Cancer Epidemiol. 2010, 34, 634-638. [CrossRef]

107. O’Rielly, D.D.; Roslin, N.M.; Beyene, J.; Pope, A.; Rahman, P. TNF-alpha-308 G/A polymorphism and responsiveness to TNF-alpha blockade therapy in moderate to severe rheumatoid arthritis: A systematic review and meta-analysis. Pharmacogenomics J. 2009, 9, 161-167. [CrossRef]

108. Tong, Q.; Zhao, L.; Qian, X.D.; Zhang, L.L.; Xu, X.; Dai, S.M.; Cai, Q.; Zhao, D.B. Association of TNF-alpha polymorphism with prediction of response to TNF blockers in spondyloarthritis and inflammatory bowel disease: A meta-analysis. Pharmacogenomics 2013, 14, 1691-1700. [CrossRef]

(C) 2018 by the authors. Licensee MDPI, Basel, Switzerland. This article is an open access article distributed under the terms and conditions of the Creative Commons Attribution (CC BY) license (http://creativecommons.org/licenses/by/4.0/). 